Original Article

\title{
Serum angiopoietin -1 as a biomarker of missed abortion
}

\author{
Heba M. Abozeid Hegazy ${ }^{1}$, Boshra N. Ali ${ }^{1}$, Hala W. Abdel Halim ${ }^{1}$, Nashwa M. Abd El-baky ${ }^{2}$ \\ ${ }^{1}$ Obstetrics and Gynaecology Department, Faculty of Medicine for Girls, Cairo, Al-Azhar University, Egypt. \\ ${ }^{2}$ Clinical Pathology Department, Faculty of Medicine for Girls, Cairo, Al-Azhar University, Egypt.
}

\begin{abstract}
Background: Missed abortion (MA) is a pregnancy with an embryo without cardiac pulsation or gestational sac without embryo without attempt for expulsion of the product of conception outside the uterus.

Objective: to detect the efficacy of serum Angiopoietin-1(Ang-1) as a biomarker of missed abortion at 6 to 8 weeks of pregnancy

Methodology: This case-control study comprised eighty pregnant women aged 20-40 years; they were divided into; A) control group which composed of 40 women with normal viable pregnancy at the 6-8 weeks of pregnancy , B) study group that included 40 women with missed abortion diagnosed by TVUS at same gestational age.

Results: This study revealed that, there was highly statistically significant decrease in serum levels of Ang-1 in missed abortion . The mean \pm SD of serum Ang-1 were $926.16 \pm 211.48(700-1620.3) \mathrm{pg} / \mathrm{ml}$ in normal pregnant women, and $700.04 \pm 87.87(435.9-797.8) \mathrm{pg} / \mathrm{ml}$ in women with missed abortion. The cutoff point was $\leq 780.99 \mathrm{pg} / \mathrm{ml} \mathrm{with} \mathrm{high}$ sensitivity and specificity (87.5.\% and $90.00 \%$ respectively). There was no correlation between the Ang-1 levels and (age, parity, and body mass index).

Conclusion: Serum levels of Ang-1 were highly significantly decreased in a status of missed abortion as early as 6 to 8 weeks of conception when compared with Ang-1 levels in normal viable pregnancies of similar gestational age which indicate its role in pathogenesis of missed abortion. Angiopoietin 1 is not a reliable biomarker for instant diagnosis of missed abortion as some patients need further transvaginal ultrasound (TVUS) and regular follow up.
\end{abstract}

JRAM 2021: 2(1):112-117

Keywords: Angiopoietin 1, missed abortion, biomarker

Submission Date: 27 September 2020

Acceptance Date: 3 October 2020

Corresponding author: Heba M. Abozeid Hegazy, obstetrics and gynaecology department, faculty of medicine for girls, Cairo, AlAzhar University, Egypt. Tel: 01015988135. E-mail: abozeidheba07@ gmail.com.

Please cite this article as: Hegazy HMA, Ali BN, Abdel Halim HW, Abdel Baki NM. Serum angiopoietin -1 as a biomarker of missed abortion. JRAM 2021: 2(1):112-117. DOI: $10.21608 /$ jram.2020.44016.1085

\section{INTRODUCTION}

Missed abortion is a disorder with retained embryo without cardiac pulsation or gestational sac without an embryo; however, the uterus is dormant yet without any trying to expel this product ${ }^{[1]}$. No symptoms for miscarriage emerge for some weeks and if exist, these may be spotting or moderate to severe bleeding per vagina with disappearance of symptoms of conception.

Signs of missed abortions appear in picture of foetal demise with closed cervix ${ }^{[2]}$. Missed abortion can be diagnosed by two successive measurements of beta human chorionic gonadotrophin (BHCG) with transvaginal ultrasound (TVUS). Some patients may need to repeat this TVUS to confirm the diagnosis. ${ }^{[3]}$

Angiopoietin-1 (Ang-1) is a member of growth factors group that is responsible for angiogenesis. It comes from the mesenchymal cells and syncytiotrophoblasts of the placenta. Ang-1 has a role in growing and sprouting of vessels in placenta, brains, and development of cardiovascular system of the fetus. The

https://jram.journals.ekb.eg

Print ISSN 2636-252X - Online ISSN 2636-2538 ease to screen Ang-1 could make it a unique test to diagnose missed abortion instantly at 6-8 weeks of gestation [4]. Therefore, this study was carried out to detect the efficacy of serum Angiopoietin-1(Ang-1) as a biomarker of missed abortion at 6 to 8 weeks of pregnancy.

\section{PATIENTS AND METHODS}

This is a case-control study was carried out at the obstetrics and gynaecology outpatient clinic at Alzahraa University Hospital in the period from August 2019 to April 2020.

Inclusion criteria: Eighty pregnant women aged 2040 years and at 6-8 weeks of gestation were incorporated in this study. They were divided to two groups:

- Control group (A) with normal viable intrauterine pregnancy coming to confirm their normal intrauterine pregnancy at the same early gestational age (6-8 weeks). The criteria for diagnosis of normal Personal non-commercial use only. JRAM copyright @ 2020. All rights reserved 
intrauterine pregnancy include at $6^{\text {th }}$ week, the embryonic pole must be seen. This pole is about 2 $10 \mathrm{~mm}$ and has cardiac pulsation. Also, this embryonic pole must be seen once the mean sac diameter (MSD) becomes $20 \mathrm{~mm}$. The maximal diameter of embryonic pole can be used for estimation of gestational age up to $9^{\text {th }}$ week of gestation ${ }^{[5]}$

- Study group (B) with missed abortion diagnosed by TVUS. Some of them had an early pregnancy of (6-8 weeks) with vaginal bleeding and on TVUS they revealed the criteria of missed abortion. Others came with BHCG +ve with no symptoms of early pregnancy. Criteria of missed abortion includes : The crown-rump length must be $\geq 7 \mathrm{~mm}$ with no pulsation, the mean sac diameter about $\geq 25 \mathrm{~mm}$ without embryo, no embryo $\geq$ two weeks after TVUS that revealed a gestational sac devoid of a yolk sac ,no embryo with pulsation $\geq$ eleven days after TVUS that showed gestational sac together with yolk sac ${ }^{[6] .}$

Exclusion Criteria: women with following disorders; multi-fetal pregnancy, medical abortion or any tumor noted, complicated $1^{\text {st }}$ trimesteric pregnancy, and women who get pregnant with in vitro fertilization were excluded from the study.

Detailed history was including presenting complaints, past, medical and gynaecological histories were noted. Body mass index (BMI) was calculated. General and local vaginal examinations were performed. Women included in the study were subjected to transvaginal ultrasound to confirm intrauterine gestational sac to exclude ectopic pregnancy and to confirm the normal viable intrauterine pregnancies and differentiate it from missed abortion.

After aseptic circumstances, samples from venous blood were collected in a serum separator tubes (SST), clotted for 10-20 minutes at room temperature after that centrifugated for 20 minutes at 2000-3000 RPM. Serum was aspirated and stored at $-80^{\circ} \mathrm{c}$ till the test. Estimation of Angiopoietin-1 was done in the serum of all women in this study using enzyme linked immunosorbent assay (ELIZA) kit. The plate precoated on the wells. Next biotinylated human Angiopoietin-1 antibody was inserted and was united with Angiopoietin -1 in the sample. Then Streptavidinhorse radish peroxidase (HRP) enzyme was inserted and was united to the biotinylated Ang-1 antibody. The unbound Streptavidin-HRP was washed away during a washing step after incubation. Substrate solution was added, and color obtains in proportion to the quantity of serum Ang-1. The reaction was completed by adding acidic stop solution then the absorbance was measured at $450 \mathrm{~nm}$.

\section{Statistical analysis}

The data were analysed by using IBM computer SPSS (statistical program for social science) version 20 . The quantitative variables were prescribed as range, mean and standard deviation. The qualitative variables were presented as number and percentage. Using Chi-square $\mathrm{d}\left(\mathrm{x}^{2}\right)$ to compare qualitative variables between the two groups. Fisher exact test was applied if an expected cell were less than 5 . Independent t-test was used to assess the quantitative variables in parametric data, (SD $<50 \%$ of the mean). Mann Whitney Wilcoxon test was applied to assess quantitative variable in nonparametric data, (SD $>50 \%$ of the mean). $\mathrm{P}$ value $>0.05$ was considered non-significant, and p-value $<0.05$ was considered significant Receiver operating characteristic curve (ROC) was used to assess the best cut off point with its sensitivity, specificity, positive predictive value (PPV), negative predictive value (NPV) and area under curve (AUC) of the Angiopoietin-1

\section{RESULTS}

In this study, there was statistically significant difference between the study group and control group regarding parity and body mass index, with higher BMI and lower parity in missed abortion group ( $\mathrm{p}=0.013$ and 0.044 , respectively). There was no statistically significant difference between both groups as regard ages and modes of delivery (Table 1). Moreover, Ang-1, levels were significantly lower in missed abortion group compared to control group (Table 2 and figure 1 ).

At cutoff point of Angiopoietin-1 level ( $\leq 780.99$ $\mathrm{pg} / \mathrm{ml}$ ), the Angiopoietin-1 level have good sensitivity and specificity $(87.5 \%$ and $90.0 \%$ respectively) for diagnosis of missed abortion at 6-8 weeks of gestation (Table 3 and figure 2).

There was overlap of the Ang-1 levels (700 - 1620.3) in control group and (435.9-797.8) in missed abortion group as shown in (Table 2). There was no correlation between the (Ang-1) levels and the age, parity, and BMI (Table 4). 
Table (1): Comparison between control group and missed abortion group as regard demographic data and obstetric history

\begin{tabular}{|c|c|c|c|c|c|}
\hline & & $\begin{array}{c}\text { Control group } \\
(\text { No. }=40)\end{array}$ & $\begin{array}{l}\text { Missed abortion } \\
\text { group }(\text { No. }=40)\end{array}$ & $\begin{array}{c}\text { Test of } \\
\text { significance }\end{array}$ & P-value \\
\hline Age (year) & $\begin{array}{l}\text { Mean } \pm \text { SD } \\
\text { Range }\end{array}$ & $\begin{array}{c}29.53 \pm 5.22 \\
20-39\end{array}$ & $\begin{array}{c}28.88 \pm 5.45 \\
20-40\end{array}$ & $0.545^{\mathrm{a}}$ & 0.587 \\
\hline Parity & $\begin{array}{l}\text { Median (IQR) } \\
\text { Range }\end{array}$ & $\begin{array}{c}3(2-4) \\
0-7\end{array}$ & $\begin{array}{c}2(0-4) \\
0-7\end{array}$ & $-2.481^{b}$ & $0.013^{*}$ \\
\hline BMI $\left(\mathrm{kg} / \mathrm{m}^{2}\right)$ & $\begin{array}{l}\text { Mean } \pm \text { SD } \\
\text { Range }\end{array}$ & $\begin{array}{c}29.03 \pm 3.56 \\
24.00-39.56\end{array}$ & $\begin{array}{c}30.69 \pm 3.7121 \\
24.91-39.56\end{array}$ & $-2.046^{a}$ & $0.044^{*}$ \\
\hline Mode of delivery & $\begin{array}{l}\text { NVD } \\
\text { CS }\end{array}$ & $\begin{array}{l}21(52.5 \%) \\
19(47.5 \%)\end{array}$ & $\begin{array}{l}21(52.5 \%) \\
19(47.5 \%)\end{array}$ & $0.001^{\mathrm{c}}$ & 1.00 \\
\hline
\end{tabular}

${ }^{\mathrm{a}}$ : student t test, ${ }^{\mathrm{b}}$ : Chi-square : Chi-square, Mann Whitney Wilcoxon test , *: significant p-value, IQR: inter quadrant range, SD: standard deviation, BMI: Body mass index, NVD=normal vaginal delivery $\mathrm{CS}=$ cesarean section

Table (2): Comparison between control group and missed abortion group as regard the value of Angiopoietin -1

\begin{tabular}{|c|c|c|c|c|}
\hline Ang-1 pg/ml & $\begin{array}{l}\text { Control group } \\
(\text { No. }=40)\end{array}$ & $\begin{array}{l}\text { Missed abortion group } \\
\qquad(\text { No. }=40)\end{array}$ & $\begin{array}{c}\text { Test of } \\
\text { significance }\end{array}$ & P-value \\
\hline $\begin{array}{l}\text { Mean } \pm \text { SD } \\
\text { Range }\end{array}$ & $\begin{array}{c}926.16 \pm 211.48 \\
700-1620.3\end{array}$ & $\begin{array}{c}700.04 \pm 87.87 \\
435.9-797.8\end{array}$ & $6.245^{\mathrm{a}}$ & $0.001 *$ \\
\hline
\end{tabular}

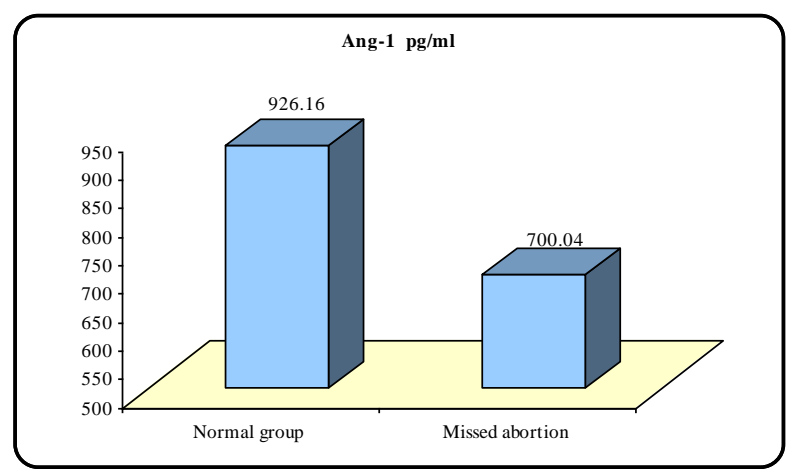

Figure (1): Bar chart between control group and missed abortion group as regard the value of Angiopoietin -1 (Ang-1) Pg/ml

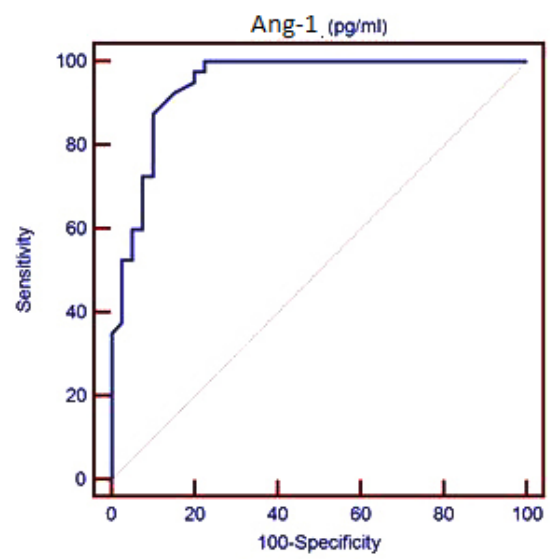

Figure (2): Receiver operating characteristic curve forAng-1 in Missed abortion

Table (3): Diagnostic performance of Ang-1 pg/ml in prediction of missed abortion

$$
\begin{aligned}
& \text { Parameter AUC Cut of Point Sensitivity Specificity PPV NPV } \\
& \begin{array}{|l|l|l|l|l|l|l|}
\hline \text { Ang-1 pg/ml } & 0.947 & \leq 780.99 & 87.5 & 90.0 & 89.7 & 87.8 \\
\hline
\end{array} \\
& \text { AUC: area under a curve, PPV: Positive predictive value, NPV: Negative predictive value }
\end{aligned}
$$

Table (4): Correlation between levels of (Ang-1) and some parameters in both groups of the study

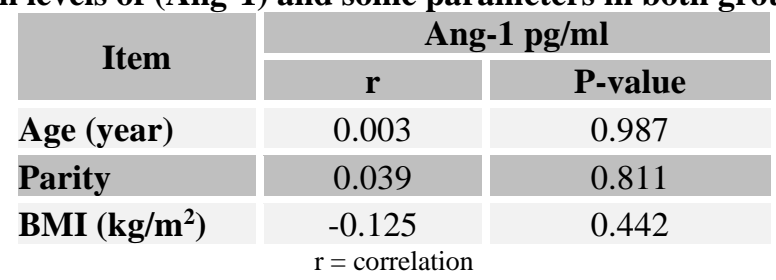




\section{DISCUSSION}

Obstetricians and gynecologists should appreciate the tools that used to differentiate between normal and failed pregnancies. Although the accurate cause and pathophysiology of abortion still unclear, it is theorized that the process of embryonic attachment to the uterus is worsened, that leads to deficient nutritional support of the embryo, inhibition of "natural selection" of viable featuses which leads to fetal demise ${ }^{[7]}$. So, this study was designed to evaluate the effectiveness of Ang-1 in serum as a biomarker for missed abortion at 6 to 8 weeks of gestation.

Regarding parity, in this study parity was statistically significantly higher in normal pregnancy group than missed abortion group, in contrast Cohain et al. ${ }^{[8]}$ found that the number of abortions increased with higher parity. Additionally, they reported that the women with high parity are oldest than those of low parity usually, which support this suggestion.

In this study, the BMI was statistically significantly higher in missed abortion group compared to control group. It is possible that extreme fat amount in obese women, produce adipokines which are adipose tissue derived proteins. The adipokine leptin has a role in placental formation and maternal-fetal exchange processes that regulate the growth of the embryo and a minor rise in leptin concentrations lead to a mild rise in BMI which may be the reason of this obvious positive effect. But, with additional rise in BMI and as the woman becomes overweight to obese, a state of leptin resistance and relative insufficiency may occur that may describe the poor reproductive act like abortion in those women ${ }^{[9]}$. This study agreed with Metwally et al. ${ }^{[10]}$ who concluded that women with a BMI $\geq 25$ $\mathrm{kg} / \mathrm{m}^{2}$ may be more susceptible to abortions. In disagreement with us Rao et al. ${ }^{[11]}$ found that BMI in normal pregnancy group was significantly higher than missed abortion group ( $24.2 \pm 2.7$ vs. $22.3 \pm 2.5) \mathrm{kg} / \mathrm{m}^{2}$ respectively.

In this study, there was no significant difference between the two groups, regarding the mode of delivery. This result was in contrast with Magnus et al. ${ }^{[12]}$ who noticed a small increase in abortion risk after cesarean section. It is possible that the motivating dilemma that caused delivery by cesarean section raises the risk of abortion in the following pregnancy. The mechanism which explain that could be uterine scarring [13]. Intrauterine scarring may cause abortions due to lack of sufficient endometrium or lining for implantation, poor blood supply or mechanical restriction of the uterine cavity expansion during pregnancy ${ }^{[14]}$ but, small sample size in this study may be the cause of such contrast.

This study demonstrated that the mean of serum Angiopoietin-1 were $926.16 \mathrm{pg} / \mathrm{ml}$ (700-1620.30) in normal pregnant women, and $700.04 \mathrm{pg} / \mathrm{ml}$ (435.9797.8) in women with missed abortion with a cutoff point $(\leq 780.99 \mathrm{pg} / \mathrm{ml})$ with high sensitivity and specificity $(87.5 \%$ and $90.0 \%$ respectively). Like Daponate et al. ${ }^{[15]}$ who demonstrated that the levels of
Ang-1 in serum were $963.5 \mathrm{pg} / \mathrm{ml}$ (793.9-1277.6) in normal pregnant women and $810.5 \mathrm{pg} / \mathrm{ml}$ (595.4917.4) in missed abortion with cutoff point of Ang-1 $(\leq 918.33 \mathrm{pg} / \mathrm{ml})$.Also, Rao et al. ${ }^{[11]}$ showed that Angiopoietin 1 values were around $1102.50 \mathrm{pg} / \mathrm{ml}$ $(1028.20-1196.30)$ in normal pregnant women and $780.50 \mathrm{pg} / \mathrm{ml}(712.3-881.8)$ in women with missed abortion.

In this study, there was not statistically significant correlation between Ang-1 and (Age, parity and BMI) of the patients in disagreement with Schneuer et al. ${ }^{[16]}$ who found that there was a positive correlation between Ang-1 and maternal weight. Also, Gaebler et al. ${ }^{[17]}$ identified a significant positive correlation of Ang-1 and body mass index. Rao et al. ${ }^{[11]}$ reported that Angiopoietin-1 is a protein that gives prompt diagnosis of missed abortion without serial measurement of Ang-1 and could be used as a marker for abortion. The ease of use this biomarker would reinforce the diagnosis conducted by ultrasonography without additional assessment and further follow-up ${ }^{[11]}$

But due to the noted overlap of the Ang-1 levels (700 $1620.3) \mathrm{pg} / \mathrm{ml}$ in normal pregnancy vs (435.9 - 797.8) $\mathrm{pg} / \mathrm{ml}$ in missed abortion in this study, Angiopoietin -1 is not a reliable biomarker for instant diagnosis of missed abortion as some patients need further TVUS and regular follow up visits.

Collectively, our findings suggest that Ang-1 levels in serum are highly significantly decreased in a condition of missed abortion compared to its levels with viable intrauterine pregnancies similar gestational age which indicate its role in pathogenesis in missed abortion. But until now Angiopoietin -1 is not used in the practice. So further studies may be needed for more confirmation of its accuracy using larger sample sizes.

\section{CONCLUSION}

Levels of Ang-1 in serum are highly significantly decreased in a condition of missed abortion as early as 6-8 weeks of gestation compared to its levels in viable intrauterine pregnancies of similar gestational age which indicate its role in pathogenesis in missed abortion. Therefore, we recommended to measure serum Ang-1 between 6 to 8 weeks of conception because at similar age the differentiation between normal viable pregnancy and abortion is doubtful in case of irregular cycles or if the patient not sure of her last menstrual period. Angiopoietin -1 is not a reliable biomarker for instant diagnosis of missed abortion as some patients need further TVUS and regular follow up visits.

\section{Future directions}

- Another study to assess measurement of Angiopoietin-2 and calculate Ang 1/Ang 2 ratio for diagnosis of pregnancy failure and compare them with measurement of Angiopoietin -1 alone to 
determine the most accurate one to be used is recommended.

Financial support and sponsorship: No

Conflicts of interest: No conflicts of interest.

\section{REFERENCES}

1. Ashaat N, Husseiny A. Correlation between missed abortion and insertional translocation involving chromosomes 1 and 7. Iranian journal of reproductive medicine 2012; 10 (1): 15 .

2. Jurkovic D, Overton C, Bender-Atik R. Diagnosis, and management of first trimester miscarriage. BMJ 2013; 346 (7913): 34-37.

3. Korevaar TI, Steegers EA, de Rijke YB, Schalekamp-Timmermans S, Visser $W$ E, Hofman A, et al. Reference ranges and determinants of total hCG levels during pregnancy: The generation $\mathrm{R}$ study. European journal of epidemiology 2015; 30(9): 1057-1066.

4. Geva E, Ginzinger D, Zaloudek C, Moore D, Byrne A, Jaffe R. Human placental vascular development: vasculogenic and angiogenic (branching and nonbranching) transformation is regulated by vascular endothelial growth factor-A, angiopoietin-1, and angiopoietin-2. The Journal of Clinical Endocrinology and Metabolism 2002; 87 (9): 4213-4224.

5. Murugan VA, Murphy BO, Dupuis C, Goldstein A, Kim YH. Role of ultrasound in the evaluation of first-trimester pregnancies in the acute setting. Ultrasonography 2019; 39(2):178189.

6. Doubilet PM, Benson CB, Bourne T, Blaivas M. Diagnostic criteria for nonviable pregnancy early in the first trimester. New England Journal of Medicine 2013; 369(15): 1443-1451.

7. ACOG Practice Bulletin No. 200 Summary: Early Pregnancy Loss. Obstet Gynecol 2018;132 (5):1311-1313.

8. Cohain JS, Buxbaum RE, and Mankuta D. Spontaneous first trimester miscarriage rates per woman among parous women with 1 or more pregnancies of 24 weeks or more. BMC pregnancy and childbirth 2017; 17(1): 437.
9. Metwally M, Saravelos SH, Ledger WL and Li TC. Body mass index and risk of miscarriage in women with recurrent miscarriage. Fertility and sterility 2010; 94(1): 290-295.

10. Metwally M, Ong KJ, Ledger WL, Li TC. Does high body mass index increase the risk of miscarriage after spontaneous and assisted conception? A meta-analysis of the evidence. Fertility and sterility 2008; 90(3): 714726.

11. Rao M, Kanwal S, Mahmud Q, Qureshi HJ, Zulfiqar S. Serum angiopoietin-1 as a biomarker of missed abortion. Pakistan Journal of Physiology 2018; 14(2): 15-17.

12. Magnus MC, Wilcox AJ, Morken NH, Weinberg CR, Håberg SE. Role of maternal age and pregnancy history in risk of miscarriage: prospective register-based study. Obstetric Anesthesia Digest 2019; 39(4), 191-192.

13. O'Neill SM, Kearney PM, Kenny LC, Henriksen TB, Lutomski JE., Greene RA, et al. Caesarean delivery, and subsequent pregnancy interval: a systematic review and metaanalysis. BMC pregnancy and childbirth 2013; 13(1):165.

14. Cakmak H, Taylor HS. Implantation failure: molecular mechanisms and clinical treatment. Human reproduction update 2011; 17(2): 242-253.

15. Daponte A, Deligeoroglou E, Pournaras S, Tsezou A, Garas A, Anastasiadou F, et al. Angiopoietin-1 and angiopoietin-2 as serum biomarkers for ectopic pregnancy and missed abortion: A case-control study. Clinica Chimica Acta 2013; 415: 145-151.

16. Schneuer FJ, Roberts CL, Ashton AW, Guilbert C, Tasevski V, Morris JM, et al. Angiopoietin 1 and 2 serum concentrations in first trimester of pregnancy as biomarkers of adverse pregnancy outcomes. American journal of obstetrics and gynecology 2014; 210(4): 345-e1.

17. Gaebler N, Haggenmüller B, Kapapa M, Serra A, Tews D, Funcke JB, et al. Age-and BMIassociated expression of angiogenic factors in white adipose tissue of children. International journal of molecular sciences 2019; 20(20): 5204. 


\section{المبحص العربي \\ الانجيوبيوتين-1 كمؤشر حيوي للإجهاض المنسي

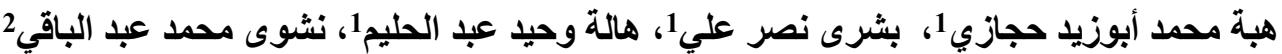

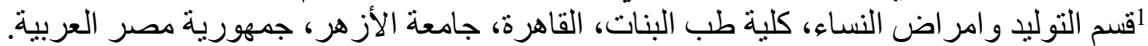 \\ 2قفم الباثولوجيا الإكلينيكية، كلية طب البنات، القاهرة، جامعة الأزهر، جمهورية مصر الأهر العربية.}

ملخص البحث

الخلقية: الإجهاض المنسي هو حمل بجنين بدون نبض أو كيس حمل بدون جنين بدون محاولة من لرحم لطرد نتائج الحمل خرجه الإنها:

الهـف: الكثف عن فعالية الانجيوبيوتين-1 في دم الإنسان ليكون مؤشراً بيولوجياً للإجهاض المنسي في عمر 6 إلى 8 أسابيع من الحمل مقارنة بمستوياته في حالات الحمل الطبيعية القابلة للحياة في ذللك العمر من الحئل الحمل..

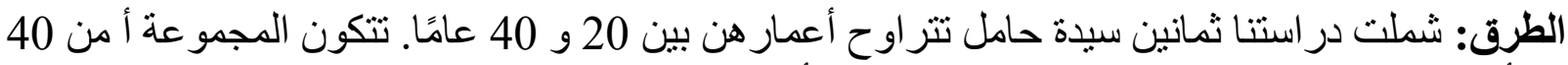

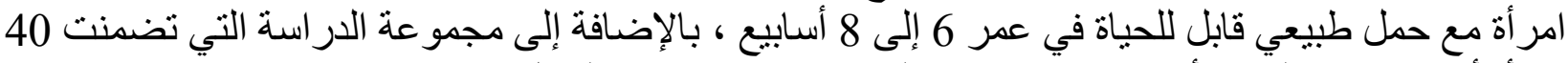

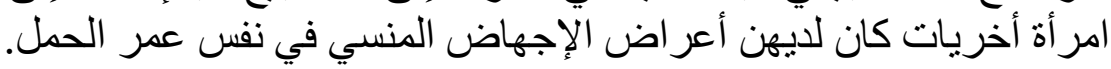

النتائج: خلصت هذه الدر اسة الى وجود انخفاض معتد به إحصائيًا في مستويات الانجيوبيونين-1 في الإجهاض

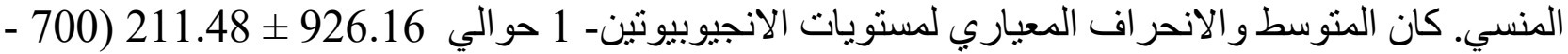

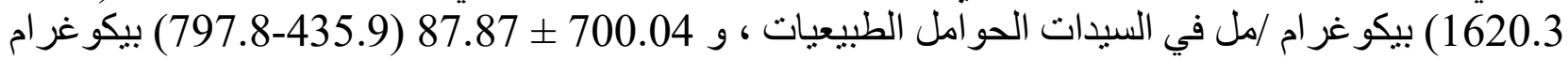
/ مل في النساء اللواتي يعانين من الإجهاض المنسي ـ كانت نقطة الفصل بين الاجهاض المنسي المنسي و الحمل

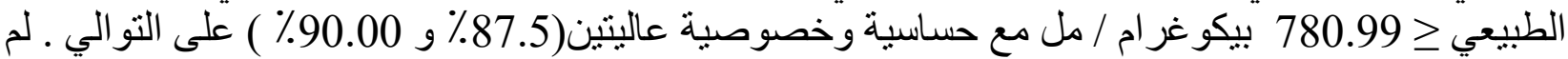
يكن هنآك ارتباط بين مستويات الانجيوبيوتين- 1 و (عمر المر أه ، عدد مر ات الو لونين لادة ، أو مؤشر كتلة الجسم ) الاستتناجات: اثناء الاجهاض المنسي في عمر الحمل المبكر من 6- 8 اسابيع تنخفض مستويات الانجيوبيوتين

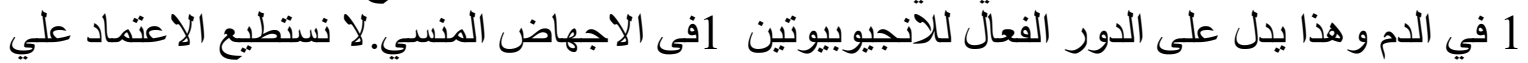

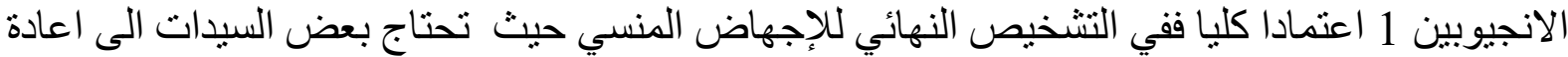

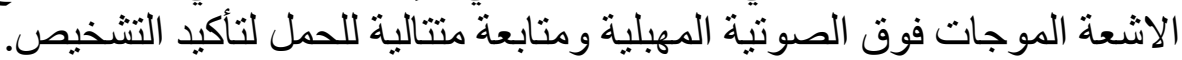

الكلمات المفتاحية: أنجيوبويتين 1، الإجهاض المنسي، مؤشر بيولوجي. الباحث الرئيسي الأسم: هبة محمد أبوزيد حجازي، قسم التوليد وامر اض النساء، كلية طب البنات، القاهرة، جامعة الأزهر، جمهورية مصر العربية. البريد الإكتروني: gabozeidheba07@gmail.com 